\title{
Microencapsulation of Lactobacillus acidophilus La-5 by spray-drying using sweet whey and skim milk as encapsulating materials
}

\author{
G. M. Maciel, ${ }^{\star}$ K. S. Chaves, ${ }^{\star}$ C. R. F. Grosso, $†$ and M. L. Gigante ${ }^{\star 1}$ \\ *Department of Food Technology, Faculty of Food Engineering, University of Campinas, UNICAMP, 13083-862, Campinas, SP, Brazil \\ †Department of Foods and Nutrition, Faculty of Food Engineering, University of Campinas, UNICAMP, 13083-862, Campinas, SP, Brazil
}

\begin{abstract}
The aim of this study was to evaluate the effect of encapsulating material on encapsulation yield, resistance to passage through simulated gastrointestinal conditions, and viability of Lactobacillus acidophilus La-5 during storage. Microparticles were produced from reconstituted sweet whey or skim milk (30\% total solids) inoculated with a suspension of $L$. acidophilus La-5 (1\% $\mathrm{vol} / \mathrm{vol}$ ) and subjected to spray-drying at inlet and outlet temperatures of $180^{\circ} \mathrm{C}$ and 85 to $95^{\circ} \mathrm{C}$, respectively. The samples were packed, vacuum-sealed, and stored at $4^{\circ} \mathrm{C}$ and $25^{\circ} \mathrm{C}$. Encapsulation yield, moisture content, and resistance of microencapsulated $L$. acidophilus La-5 compared with free cells (control) during exposure to in vitro gastrointestinal conditions $(\mathrm{pH} 2.0$ and 7.0) were evaluated. Viability was assessed after $0,7,15,30,45$, 60 , and $90 \mathrm{~d}$ of storage. The experiments were repeated 3 times and data were analyzed by ANOVA and Tukey test for the comparison between means. The encapsulating material did not significantly affect encapsulation yield, average diameter, or moisture of the particles, which averaged $76.58 \pm 4.72 \%, 12.94 \pm 0.78 \mu \mathrm{m}$, and $4.53 \pm 0.32 \%$, respectively. Both microparticle types were effective in protecting the probiotic during gastrointestinal simulation, and the skim milk microparticles favored an increase in viability of $L$. acidophilus La-5. Regardless of the encapsulating material and temperature of storage, viability of the microencapsulated $L$. acidophilus La-5 decreased on average $0.43 \mathrm{log} \mathrm{cfu} / \mathrm{g}$ at the end of $90 \mathrm{~d}$ of storage, remaining higher than $10^{6}$ $\mathrm{cfu} / \mathrm{g}$.
\end{abstract}

Key words: probiotic, spray-drying, microencapsulation, gastrointestinal simulation

\section{INTRODUCTION}

The food industry's interest in developing new functional food products has increased together with consumer awareness and concern about nutrition. Foods

Received September 6, 2013.

Accepted December 19, 2013.

${ }^{1}$ Corresponding author: mirna@fea.unicamp.br with probiotics stand out in this market. Although scientific studies about the effectiveness of probiotics are recent and certain regulatory challenges remain, the worldwide probiotic market is predicted to approach US $\$ 30$ billion by 2015 (Tappenden, 2012).

Probiotics in foods are usually transient in nature, being unable to establish and replicate in the human gastrointestinal tract; thus, continuous consumption of probiotics is recommended to obtain the associated benefits (O'Toole and Cooney, 2008). The minimum dose of probiotics varies greatly depending on the product and the bacterial strain. In spite of the fact that the amount of viable probiotic in products varies from $10^{9}$ to $10^{10} \mathrm{cfu} /$ dose, some products have proven to be effective at lower levels, whereas others require larger doses (Gaurner et al., 2008).

Microencapsulation is an advantageous technology for the delivery and storage of probiotic cultures (Mortazavian et al., 2007; Manojlović et al., 2010). Among microencapsulation techniques, spray-drying has a low operating cost and appears to be a good alternative for large-scale production of powdered microbial cultures with low moisture content (Gardiner et al., 2000; Corcoran et al., 2004), higher storage stability than frozen or fresh cultures (Zhao et al., 2008; Peighambardoust et al., 2011), good viability and functionality when subjected to simulated gastrointestinal conditions (Reddy et al., 2009; De Castro-Cislaghi et al., 2012), and the possibility of storage at room temperature (Ananta et al., 2005; Chávez and Ledeboer, 2007; Oliveira et al., 2007).

Different food materials have been used for the encapsulation of probiotics by spray-drying, such as starches (O'Riordan et al., 2001; Goderska and Czarnecki, 2008; Ying et al., 2010), maltodextrin (Lian et al., 2002; Reddy et al., 2009), gums (Chávez and Ledeboer, 2007; Rodríguez-Huezo et al., 2007; Zhao et al., 2008), gelatin (Lian et al., 2002), whey proteins (Picot and Lacroix, 2004; Rodríguez-Huezo et al., 2007; Ying et al., 2010), sweet whey (De Castro-Cislaghi et al., 2012), and reconstituted skim milk (Simpson et al., 2005; Golowczyc et al., 2010). Among these materials, skim milk has proved to be a powerful protector of cell viability during spray-drying (Fu and Chen, 2011; García, 2011; Silva 
et al., 2011; Paéz et al., 2012). Several authors suggest that the efficiency of the dairy matrix in protecting cell viability during drying is related to the presence of milk components (Ananta et al., 2005; Fu and Chen, 2011). During water removal, lactose is thought to interact with the polar head groups of phospholipids and proteins of the cell membrane, thereby minimizing damage to the membrane during spray-drying and prolonged storage (Crowe et al., 2002; Ananta et al., 2005; Santivarangkna et al., 2008a,b).

Microencapsulation has been proposed to improve the survival of probiotic strains to the drastic conditions found in the upper gastrointestinal tract (Picot and Lacroix, 2004; Prakash et al., 2011; Paéz et al., 2012). Although in vitro simulation does not predict responses on the functionality of these microorganisms in the human body, it is helpful in assessing survival of probiotics in different food matrices during passage through the gastrointestinal tract (Lian et al., 2003; Buriti et al., 2010; Paéz et al., 2012). In addition to the food matrix, the probiotic's resistance to the simulated gastrointestinal conditions depends on intrinsic characteristics of each strain and different testing conditions, such as choice of $\mathrm{pH}$, presence and source of enzymes, and temperature and time of incubation (Fávaro-Trindade and Grosso, 2002; Del Piano et al., 2006a,b, 2008; Guerra et al., 2012).

Dairy matrices are beneficial for encapsulation of lactic acid and probiotic bacteria, and their effectiveness in protecting cell viability during drying is related to the presence of lactose and milk proteins in these matrices. It is also known that the digestibility of casein and whey proteins is different, which may affect the viability of microorganism during passage through the gastrointestinal tract. However, no studies have been done to compare the effectiveness of 2 different dairy matrices on the microencapsulation and functionality of Lactobacillus acidophilus La-5, and the implications for developing alternative microencapsulation to maintain viability of the probiotic at room temperature. Thus, the aim of this study was to compare the influence of skim milk and sweet whey, dairy matrices with different lactose and protein contents and different protein profiles, on the encapsulation yield of Lactobacillus acidophilus La-5, resistance of the probiotic to the passage through simulated gastrointestinal conditions, and its viability during $90 \mathrm{~d}$ of storage at 4 and $25^{\circ} \mathrm{C}$.

\section{MATERIALS AND METHODS}

\section{Probiotic Culture Preparation}

To maintain the L. acidophilus La-5 culture (Chr. Hansen, Valinhos, Brazil), direct vat set culture (25 g) was suspended in $1 \mathrm{~L}$ of $12 \%$ (wt/vol) autoclaved reconstituted skim milk $\left(121^{\circ} \mathrm{C} / 10 \mathrm{~min}\right)$, followed by addition of $10 \%$ (wt/vol) autoclaved glycerol $\left(121^{\circ} \mathrm{C} / 15\right.$ $\min )$ at $15^{\circ} \mathrm{C}$. This mixture was fractionated into $1-\mathrm{mL}$ aliquots and frozen at $-18^{\circ} \mathrm{C}$ until use. To obtain the probiotic cell suspension for encapsulation, the frozen culture was reactivated twice in de Man, Rogosa, and Sharpe (MRS) broth (1\% vol/vol; Becton, Dickinson and Co., Franklin Lakes, NJ) and incubated at $37^{\circ} \mathrm{C}$ for $15 \mathrm{~h}$. After this period, the cell suspension was centrifuged at $3,000 \times g$ for $10 \mathrm{~min}$ at $4^{\circ} \mathrm{C}$. The concentrated cells obtained after centrifugation were washed twice with sterile peptone solution $(0.1 \% \mathrm{wt} / \mathrm{vol})$, with subsequent disposal of the supernatant and centrifugation as previously described. After the second wash, the cell concentrate was resuspended into $0.1 \%$ peptone solution.

\section{Production and Storage of Probiotic Microparticles}

Solutions with $30 \%$ TS $(1.5 \mathrm{~L})$ were prepared from skim milk powder (Molico, Nestlé Brasil Ltda, Araçatuba, SP, Brazil) or sweet whey powder (Laticínios Porto Alegre, Mutum, MG, Brazil) reconstituted in sterile water $\left(121^{\circ} \mathrm{C} / 15 \mathrm{~min}\right)$ at room temperature. The solutions were maintained under stirring at $450 \mathrm{rpm}$ for $30 \mathrm{~min}$ to improve reconstitution of the powder. After this time, $1 \%$ (vol/vol) of L. acidophilus La-5 cell suspension was added to each solution. Then, reconstituted sweet whey or skim milk was atomized for drying and microencapsulation of L. acidophilus La-5 in a laboratory-scale spray-dryer (Lab-Plant SD-05; Lab-Plant, Huddersfield, UK) using inlet and outlet temperatures of 180 and $85-95^{\circ} \mathrm{C}$, respectively, air pressure of 5.0 $\mathrm{kgf} / \mathrm{cm}^{2}$, flow rate of $8.0 \mathrm{~mL} / \mathrm{min}$, and nozzle diameter of $1.5 \mathrm{~mm}$.

After spray-drying, 2 distinct products were obtained: sweet whey microparticles $\left(\mathbf{S W}_{\mathbf{M P}}\right)$ and skim milk microparticles $\left(\mathbf{S M}_{\mathbf{M P}}\right)$ containing L. acidophilus La-5. Portions of $5 \mathrm{~g}$ were packed in metallized polyester-polyethylene packaging (Tradbor Ltda., Iperó, SP, Brazil), vacuum-sealed, stored in desiccators containing silica gel, and incubated at $4 \pm 1^{\circ} \mathrm{C}$ and $25 \pm 1^{\circ} \mathrm{C}$ for $90 \mathrm{~d}$.

\section{Characterization of Encapsulating Materials and Microparticles}

The encapsulating materials, reconstituted sweet whey and skim milk with $30 \%$ TS, were analyzed for pH (pH meter DM22-Digimed, São Paulo, SP, Brazil), TS (method 990.19; AOAC International, 2006), total $\mathrm{N}$ by Kjeldahl (method 991.20, AOAC International, 2006), total fat by Mojonnier (method 989.05, AOAC 
International, 2006), and ash content (method 945.46, AOAC International, 2006). Lactose content was calculated by the difference between TS and other constituents of milk solids. The newly produced microparticles were analyzed for moisture by oven drying at $102^{\circ} \mathrm{C}$, as described by the International Dairy Federation (IDF, 1993) and mean particle size (Mastersizer 2000, Malvern Instruments Ltd., Malvern, UK) using dehydrated alcohol as dispersing medium, as described by Zhao et al. (2008). All analyses were performed in triplicate. To evaluate the microstructure, the particles were sprayed on a copper conductive tape previously fixed in aluminum stubs $(1 \times 1 \mathrm{~cm})$ and coated with a gold layer $(180$ s, $40 \mathrm{~m} \AA$ current) using an evaporator Baltzer (Sputter Coater SCD50, Bal-Tec, Wiesbaden-Nordenstadt, Germany). The samples were then evaluated in a scanning electron microscope (model JMS-T300, Jeol, Tokyo, Japan) with accelerating voltage of $20 \mathrm{kV}$.

\section{Enumeration of L. acidophilus La-5 and Encapsulation Yield}

The viability of $L$. acidophilus La- 5 was determined by counting viable cells in both encapsulating materials after inoculation and in the microparticles $\left(\mathrm{SW}_{\mathrm{MP}}\right.$ and $\mathrm{SM}_{\mathrm{MP}}$ ) immediately after production (time zero) and $7,15,30,45,60$, and $90 \mathrm{~d}$ of storage at $4 \pm 1$ and $25 \pm 1^{\circ} \mathrm{C}$. One milliliter of encapsulating material was diluted into $9 \mathrm{~mL}$ of saline peptone solution ( $\mathrm{pH} 7.20$ \pm 0.02 ). To evaluate the viability of microencapsulated probiotic, $1 \mathrm{~g}$ of each sample was resuspended in $9 \mathrm{~mL}$ of saline peptone solution, stirred by vortexing for $1 \mathrm{~min}$, and allowed to stand at room temperature $\left(\sim 25^{\circ} \mathrm{C}\right)$ for 20 min to reconstitute the powder. Serial dilutions were performed in saline peptone solution followed by pour plating on MRS agar and incubation at $37^{\circ} \mathrm{C}$ for $72 \mathrm{~h}$ in anaerobic jars using the GasPak system (Becton, Dickinson and Co.). The population of L. acidophilus La-5 was determined by counting the colony-forming units. The encapsulation yield (EY) was calculated according to Reddy et al. (2009) with modifications, and is presented in equation [1]:

$$
\mathrm{EY}=\left(\log N / \log N_{0}\right) \times 100,
$$

where $N$ is the number of viable cells (cfu/g of DM) in the powder and $N_{0}$ is the number of viable cells (cfu/g of DM) in the encapsulating material before drying.

\section{Preparation of the Artificial Gastric and Intestinal Juices}

The artificial gastric and intestinal juices were prepared according to Gerez et al. (2012) and Souza et al. (2012), with modifications. The artificial gastric juice (AGJ) was prepared using calcium chloride (0.11 $\mathrm{g} / \mathrm{L})$, potassium chloride $(1.12 \mathrm{~g} / \mathrm{L})$, sodium chloride $(2.0 \mathrm{~g} / \mathrm{L})$, and potassium phosphate monobasic $(0.4$ $\mathrm{g} / \mathrm{L})$ followed by sterilization at $121^{\circ} \mathrm{C} / 15 \mathrm{~min}$. Mucin $(3.5 \mathrm{~g} / \mathrm{L})$ and pepsin $(0.26 \mathrm{~g} / \mathrm{L})$ of porcine origin (Sigma-Aldrich Co., St. Louis, MO) were added to AGJ immediately before using, and the $\mathrm{pH}$ was adjusted to 2.0 with $1 \mathrm{~N} \mathrm{HCl}$. The artificial intestinal juice was prepared by adding pancreatine (Sigma-Aldrich Co.) to the AGJ after the gastric simulation, to obtain a final concentration of $1.95 \mathrm{~g} / \mathrm{L}$, and the $\mathrm{pH}$ was adjusted to 7.0 by addition of $1 \mathrm{~N} \mathrm{NaHCO}_{3}$.

\section{Simulation of Gastrointestinal Conditions}

After produced, $3 \mathrm{~g}$ of the different microparticles $\left(\mathrm{SW}_{\mathrm{MP}}\right.$ and $\left.\mathrm{SM}_{\mathrm{MP}}\right)$ or $3 \mathrm{~mL}$ of the concentrate containing free cells of $L$. acidophilus La- 5 were added separately into test tubes containing $30 \mathrm{~mL}$ of AGJ $(\mathrm{pH} 2.0)$ and incubated at $37^{\circ} \mathrm{C}$ in a metabolic bath with stirring. Viability was assessed at time intervals of 0,60 , and $120 \mathrm{~min}$ of exposure to AGJ. After 120 min of gastric simulation, pancreatine was added to the tubes and the $\mathrm{pH}$ was adjusted to 7.0 to initiate the intestinal simulated phase. Viability was assessed after 300 min of contact with the artificial intestinal juice, following the procedures described in the Enumeration of L. acidophilus La-5 and Encapsulation Yield section.

\section{Experimental Design and Statistical Analysis}

Comparison of the composition of reconstituted skim milk and sweet whey, as well as the effect of the encapsulating material on moisture content, mean particle size, and encapsulation yield were evaluated by ANOVA and Tukey test $(P<0.05)$ for comparison between means. To evaluate survival of $L$. acidophilus La-5 during gastrointestinal simulation, a $3 \times 4$ factorial scheme in a randomized complete block design was used. The primary factor was the treatment with 3 levels of variation (free L. acidophilus La-5 cells, $\mathrm{SW}_{\mathrm{MP}}$, and $\mathrm{SM}_{\mathrm{MP}}$ ) and the secondary factor was the time of exposure to gastrointestinal juices, with 4 levels of variation $(0,60$, 120 , and $300 \mathrm{~min}$ ). For viability of $L$. acidophilus La-5 during storage of the microparticles, a $2 \times 2 \times 7$ factorial scheme in a randomized complete block design was used. The primary factor was encapsulating material, with 2 levels of variation (skim milk and sweet whey), the secondary factor was storage temperature with 2 levels of variation $\left(4 \pm 1\right.$ to $\left.25 \pm 1^{\circ} \mathrm{C}\right)$, and the third factor was storage time with 7 levels of variation $(0$, $7,15,30,45,60$, and $90 \mathrm{~d})$. The effect of the factors and their interactions on the survival or viability of $L$. 
Table 1. Characteristics of the encapsulating materials, microparticles, and encapsulation yield of Lactobacillus acidophilus La-5 (mean $\pm \mathrm{SD}, \mathrm{n}=3$ )

\begin{tabular}{|c|c|c|c|}
\hline \multirow[b]{2}{*}{ Characteristic } & \multicolumn{2}{|c|}{ Encapsulating material ${ }^{1}$} & \multirow[b]{2}{*}{$P$-value } \\
\hline & RSW & RSM & \\
\hline Total solids (\%) & $29.9 \pm 0.14^{\mathrm{a}}$ & $30.19 \pm 0.31^{\mathrm{a}}$ & 0.12 \\
\hline Total protein (\%) & $3.86 \pm 0.03^{\mathrm{b}}$ & $9.80 \pm 0.03^{\mathrm{a}}$ & 0.00 \\
\hline Fat $(\%)$ & $0.64 \pm 0.02^{\mathrm{a}}$ & $0.41 \pm 0.03^{\mathrm{b}}$ & 0.007 \\
\hline $\operatorname{Ash}(\%)$ & $2.16 \pm 0.08^{\mathrm{b}}$ & $3.23 \pm 0.09^{\mathrm{a}}$ & 0.002 \\
\hline \multirow[t]{3}{*}{ Lactose $(\%)$} & $23.24 \pm 0.12^{\mathrm{a}}$ & $16.75 \pm 0.40^{\mathrm{b}}$ & 0.001 \\
\hline & \multicolumn{2}{|c|}{ Microparticles $^{2}$} & \\
\hline & $\mathrm{SW}_{\mathrm{MP}}$ & $\mathrm{SM}_{\mathrm{MP}}$ & \\
\hline Moisture (\%) & $4.79 \pm 0.10^{\mathrm{a}}$ & $4.28 \pm 0.22^{\mathrm{a}}$ & 0.10 \\
\hline Mean size $(\mu \mathrm{m})$ & $13.02 \pm 0.83^{\mathrm{a}}$ & $12.86 \pm 0.03^{\mathrm{a}}$ & 0.82 \\
\hline Encapsulation yield (\%) & $75.43 \pm 4.03^{\mathrm{a}}$ & $77.73 \pm 5.95^{\mathrm{a}}$ & 0.61 \\
\hline
\end{tabular}

${ }^{\mathrm{a}, \mathrm{b}}$ Means within a row with different superscripts differ $(P<0.05)$.

${ }^{1} \mathrm{RSW}=$ reconstituted sweet whey with $30 \%$ total solids; RSM $=$ reconstituted skim milk with $30 \%$ total solids.

${ }^{2} \mathrm{SW}_{\mathrm{MP}}=$ sweet whey microparticles; $\mathrm{SM}_{\mathrm{MP}}=$ skim milk microparticles.

acidophilus La-5 was assessed by ANOVA and Tukey test at $5 \%$ significance level using the software Statistica 7.0 (StatSoft Inc., Tulsa, OK). All experiments were repeated 3 times. For statistical evaluation, the probiotic counts were transformed to $\log _{10}$ and a $\mathrm{Q}-\mathrm{Q}$ plot test was performed to verify the normality of the data (R Development Core Team, 2011).

\section{RESULTS AND DISCUSSION}

\section{Encapsulating Material, Microparticles, and Encapsulation Yield}

The composition of the encapsulating material, microparticle characteristics, and encapsulation yields are shown in Table 1. The different composition of the encapsulating materials is consistent with the differences between their original raw materials (data not shown) and did not significantly affect moisture content, mean particle size, or encapsulation yield of L. acidophilus La-5. Both microparticles showed moisture contents below $5.0 \%$, which is recommended for preventing cell death during storage of dried cultures (Ledeboer and Chávez and Ledeboer, 2007; Peighambardoust et al., 2011). However, the microparticles had moisture contents slightly higher than the level required to prevent caking, which is $4 \%$ for skim milk powder and $3.0 \%$ for whey powder (Schuck, 2011). Caking, a common defect of dairy powders, is due to the absorption of water by the hygroscopic amorphous lactose, which is converted into crystals of $\alpha$-lactose monohydrate, promoting binding of the powder particles together (Fox and McSweeney, 1998), which is undesirable for survival of probiotics during storage (Chávez and Ledeboer, 2007). Packages that confer protection from water vapor are commonly used for packing dairy powders and were used in the current study. Indeed, in scale-up production, the particle moisture content could be decreased to the recommended levels for avoiding caking.

The use of encapsulating materials with similar TS content $(\sim 30 \%)$ and the constancy of the drying equipment conditions and processing parameters resulted in microparticles with mean size of $12.94 \pm 0.78 \mu \mathrm{m}$ (Table 1). Particles of similar size $(11.2 \mu \mathrm{m})$ and morphology were obtained by De Castro-Cislaghi et al. (2012) for the encapsulation of Bifidobacterium Bb-12 using sweet whey and a one-stage laboratory-scale spray-dryer. With respect to morphology (Figure 1), microparticles showed occluded air in vacuoles and the typical concavities obtained with one-stage spray-drying (Nijdam and Langrish, 2005). The similarity in morphology and size between the microparticles suggested that both had similar wettability, dispersibility, and solubility characteristics when rehydrated.

Both encapsulating materials resulted in high encapsulation yields of $L$. acidophilus La-5 (Table 1 ). The average encapsulation yield was $76.58 \pm 4.72 \%$, being $75.43 \pm 4.031 \%$ for $\mathrm{SW}_{\mathrm{MP}}$ and $77.73 \pm 5.95 \%$ for the $\mathrm{SM}_{\mathrm{MP}}$, corresponding to probiotic counts of $7.08 \pm$ 0.36 and $7.27 \pm 0.57 \mathrm{log} \mathrm{cfu} / \mathrm{g}$, respectively. Several authors suggest that the effectiveness of dairy carriers in protecting cell viability during drying is related to the presence of lactose and milk proteins, which may interact with the cell membrane of the microorganisms, preventing the leakage of the membrane during water removal (García, 2011). The removal of water bound to phospholipids changes the physical status of the cell membrane, which transits from a liquidcrystalline phase to a leak gel phase (Santivarangkna et al., 2008a). It is possible that, during drying, the 

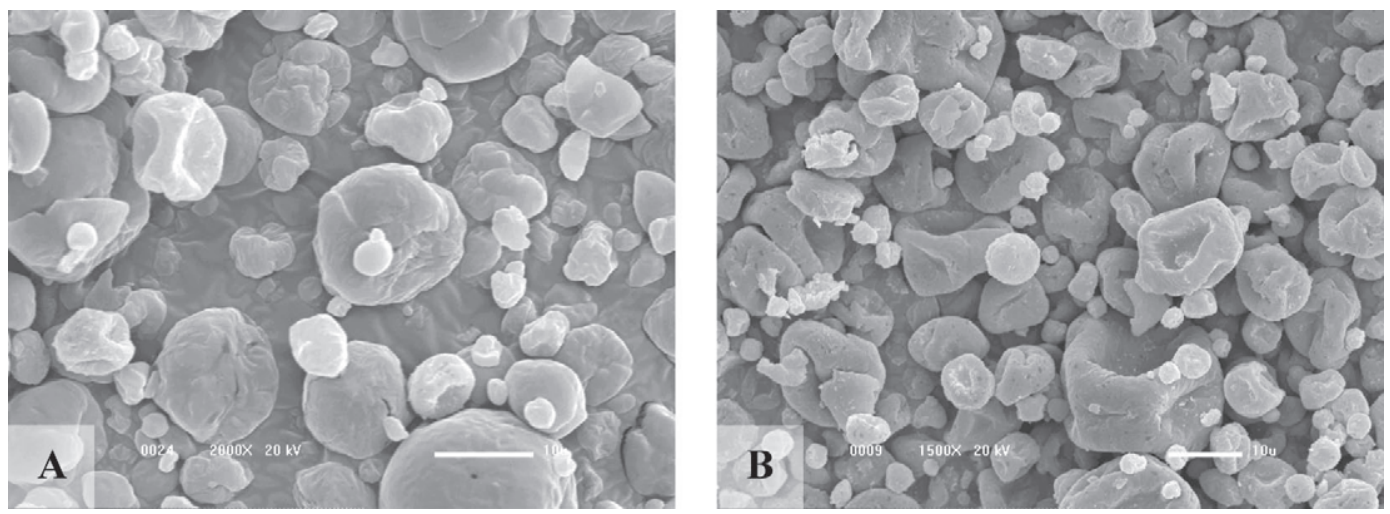

Figure 1. Scanning electron microscopy: (A) sweet whey microparticles $(2,000 \times$ magnification; bar $=10 \mu \mathrm{m}) ;(B)$ skim milk microparticles $(1,500 \times$ magnification; bar $=10 \mu \mathrm{m})$.

interaction between the cell membrane phospholipids and mainly lactose promotes the depression of the membrane phase transition, avoiding its leakage and improving bacterial recovery after rehydration (Crowe et al., 2002; Ananta et al., 2005; Santivarangkna et al., 2008a,b). In this study, both encapsulating materials contained protein and lactose (Table 1), although the reconstituted sweet whey had a higher lactose content $(\sim 39 \%)$ and lower protein content $(\sim 61 \%)$ than the reconstituted skim milk. Beyond the difference in protein content, these materials also differed in protein profiles, as reconstituted sweet whey predominantly has $\beta-\mathrm{LG}$ and $\alpha-\mathrm{LA}$ and reconstituted skim milk mainly caseins (Fox and McSweeney, 1998). Despite the difference in the concentration of lactose and protein, encapsulation yield was not affected, suggesting a compensatory effect between the protein and lactose contents of the materials or a synergistic effect of both components in protecting the probiotic against drying. According to Morgan et al. (2006), a mixture of proteins and sugars seems to be the most effective carrier in protecting microorganisms during drying. However, the mechanism by which lactose and the different proteins in dairy matrices interact and provide protection to the cell membrane during drying is still unclear (Santivarangkna et al., 2008a; Fu and Chen, 2011; García, 2011).

\section{Survival of Lactobacillus acidophilus La-5 During Storage}

The encapsulating material, temperature, and storage time significantly affected the viability of $L$. acidophilus La-5 (Table 2). The viability of the probiotic in $\mathrm{SW}_{\mathrm{MP}}$ was significantly lower than that in $\mathrm{SM}_{\mathrm{MP}}$, with average counts of $6.95 \pm 0.12$ and $7.09 \pm 0.12 \log \mathrm{cfu} / \mathrm{g}$, respectively. At $4^{\circ} \mathrm{C}$, the microcapsules had an average probiotic count of $7.11 \pm 0.12 \mathrm{log} \mathrm{cfu} / \mathrm{g}$, significantly higher than that of microcapsules stored at $25^{\circ} \mathrm{C}$, which was $6.94 \pm 0.06 \log \mathrm{cfu} / \mathrm{g}$. Storage at $5^{\circ} \mathrm{C}$ also resulted in a smaller decrease of Lactobacillus acidophilus $\mathrm{Ki}$, Lactobacillus paracasei L26, and Bifidobacterium animalis BB-12 viable cells in whey protein-based microcapsules compared with storage at $22^{\circ} \mathrm{C}$ (RodríguezHuezo et al., 2007). The viability of $L$. acidophilus La-5 decreased significantly during the 90-d storage, showing an average reduction of $0.43 \mathrm{log} \mathrm{cfu} / \mathrm{g}$ at the end of this period. Regardless of encapsulating material or storage temperature, the pattern of reduction in probiotic count was similar for all treatments and, even after $90 \mathrm{~d}$ of storage, probiotic viability remained higher than $10^{6}$ $\log \mathrm{cfu} / \mathrm{g}$ (Figure 2), the threshold value recommended for a food to exert its probiotic benefits (HamiltonMiller et al., 1999; Reid et al., 2003).

The maintenance of high counts after $90 \mathrm{~d}$ of storage, as presented in this study, may be attributed to several factors, such as the intrinsic resistance characteristics of the strain, the encapsulating material, the low moisture content of the particles, and the type of packaging (Morgan et al., 2006; Chávez and Ledeboer, 2007; Abe et al., 2009). The barrier characteristics of the packaging material and the vacuum sealing may have contributed to the microbiological stability of the microparticles during storage. Polyethylene is a good barrier against water vapor, polyester is a well-known gas barrier, and the metallization functions as a light barrier, preventing photooxidation of the material, and vacuum sealing minimizes the oxygen levels in the interior of the package (Alves et al., 2008). The barrier characteristics of the packaging material might contribute to the minimization of free radical formation, which occurs mainly by oxidation of the cell membrane lipids. When free radicals are diffused into the cell they may induce damages to cellular DNA, causing cell death (Santivarangkna et al., 2008a). Furthermore, the water vapor barrier afforded by the polyethylene present in the packing may have contributed to maintaining the 


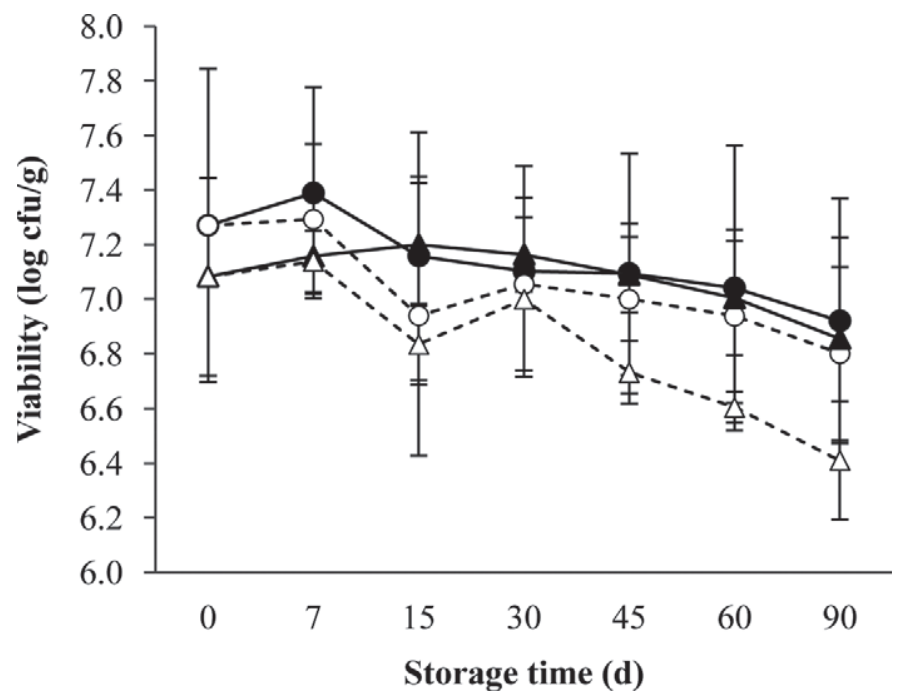

Figure 2. Variation in the viability $(\log \mathrm{cfu} / \mathrm{g})$ of Lactobacillus acidophilus La-5 in sweet whey microparticles stored at $4^{\circ} \mathrm{C}(\boldsymbol{\Delta})$ or $20^{\circ} \mathrm{C}$ $(\Delta)$ and in skim milk microparticles stored at $4^{\circ} \mathrm{C}(\bullet)$ or $20^{\circ} \mathrm{C}(\bigcirc)$. Error bars represent the standard deviation $(\mathrm{n}=3)$

vitreous state of lactose, thus minimizing oxygen diffusion to the cell membrane, favoring consequently the probiotic survival during storage (Teixeira et al., 1996; Chávez and Ledeboer, 2007).

\section{Survival of Lactobacillus acidophilus La-5 Under Simulated Gastrointestinal Conditions}

Figure 3 shows the viability of free and microencapsulated L. acidophilus La-5 subjected to simulated gastrointestinal conditions. After a 60-min exposure to AGJ, no significant reduction in viability was observed for free or microencapsulated probiotics in sweet whey or skim milk. However, after $7 \mathrm{~h}$ of gastrointestinal simulation, L. acidophilus La-5 in the free form presented a significant reduction of $3.11 \log$ cycles, whereas the probiotic microencapsulated in sweet whey had maintained its count and that microencapsulated in skim milk significantly increased $1.64 \mathrm{log}$ cycles. The recovery of probiotics at the end of the gastrointestinal simulation may be attributed to the neutral $\mathrm{pH}$ of the intestinal phase (Picot and Lacroix, 2004). However, we suggest that the highest recovery of the microorganism microencapsulated in skim milk compared with sweet whey may be due to protein digestion during passage through the gastrointestinal tract. Although caseins are digested under gastric conditions, releasing peptides and amino acids that favor the probiotic development (Brody, 2000; Brück et al., 2006), whey proteins in the native state are not hydrolyzed in vitro or in vivo by gastric juice enzymes (Kitabatake and Kinekawa, 1998). Moreover, exposure of alginate microparticles
Table 2. Effect of treatment, temperature, storage time and their interactions on the viability of Lactobacillus acidophilus La-5 ( $\mathrm{n}=3$ )

\begin{tabular}{lcc}
\hline Factor $^{1}$ & df & $P$-value \\
\hline Treatment & 1 & 0.03 \\
Temperature & 1 & 0.007 \\
Time & 6 & 0.001 \\
Treatment $\times$ Temperature & 1 & 0.22 \\
Treatment $\times$ Time & 6 & 0.94 \\
Temperature $\times$ Time & 6 & 0.78 \\
Treatment $\times$ Temperature $\times$ Time & 6 & 0.97
\end{tabular}

${ }^{1}$ Treatment $=$ encapsulating material (reconstituted sweet whey or reconstituted skim milk); temperature $=4$ or $25^{\circ} \mathrm{C}$; time $=0,7,15$, $30,45,60$, and $90 \mathrm{~d}$ of storage.

covered with native whey proteins indicates that $\beta$-LG, the main protein in sweet whey, remains intact (Gbassi et al., 2009). Thus, compared with free microorganisms, survival of the microencapsulated $L$. acidophilus La-5 was significantly higher at the end of the simulated gastrointestinal conditions, indicating the protective effect of microencapsulation in both materials. The protective effect of the skim milk and sweet whey using the same encapsulation technique was observed by other authors for different microorganisms. Lactobacillus plantarum CFR 2158100 maintained $100 \%$ viability when microencapsulated by spray-drying using skim milk and exposed to $\mathrm{pH} 2.0$ for $4 \mathrm{~h}$ (Reddy et al., 2009), whereas free cells of Bifidobacterium animalis Bb-12 decreased by $1.51 \mathrm{log} \mathrm{cfu} / \mathrm{g}$ after exposure to $\mathrm{pH} 2.0$ for $3 \mathrm{~h}$ and by $0.73 \mathrm{log} \mathrm{cfu} / \mathrm{g}$ when microencapsulated in sweet whey (De Castro-Cislaghi et al., 2012).

The resistance of the probiotic bacteria to gastrointestinal conditions, besides being dependent on the bacterial strain, appears to depend on the microencapsulation technique, addition of protective substances, or the food matrix in which probiotics are delivered. In this context, skim milk and whey and its derivatives, such as whey protein isolate and concentrate, are potential encapsulating materials for the production of capsules resistant to the gastrointestinal tract (Lian et al., 2003; Reddy et al., 2009; Ranadheera et al., 2010; Gbassi et al., 2011; Paéz et al., 2012).

\section{CONCLUSIONS}

The use of reconstituted sweet whey or reconstituted skim milk as encapsulating material did not affect the encapsulation yield of $L$. acidophilus La-5, which was approximately $80 \%$ for both materials. Regardless of the encapsulating material, the probiotic count remained above $10^{6} \mathrm{cfu} / \mathrm{g}$ after $90 \mathrm{~d}$ of storage at both storage temperatures $\left(4^{\circ} \mathrm{C}\right.$ and $\left.25^{\circ} \mathrm{C}\right)$. Both microparticles conferred protection to L. acidophilus La-5 during exposure to simulated gastrointestinal conditions 


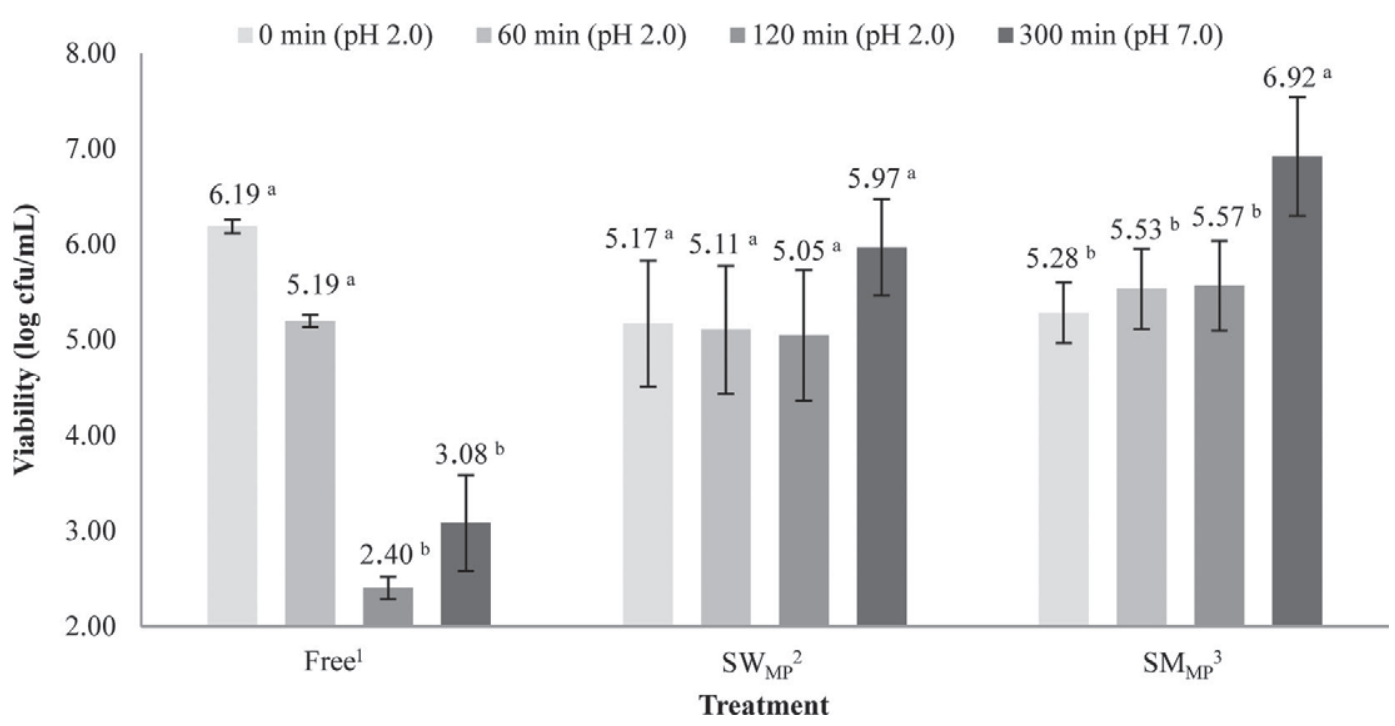

Figure 3. Viability $(\log \mathrm{cfu} / \mathrm{mL})$ of free or microencapsulated in sweet whey $\left(\mathrm{SW}_{\mathrm{MP}}\right)$ and skim milk $\left(\mathrm{SM}_{\mathrm{MP}}\right)$ Lactobacillus acidophilus La-5 during exposure to conditions that simulate gastrointestinal transit. ${ }^{\mathrm{a}, \mathrm{b}}$ For each treatment, means with different letters differ $(P<0.05)$; error bars represent the standard deviation $(\mathrm{n}=3)$.

compared with the free microorganism. Moreover, the skim milk microparticle allowed an increase in the viability of the probiotic. Both skim milk and sweet whey are suitable materials to maintain the viability of $L$. acidophilus La-5 stored at room temperature without reducing its viability when subjected to conditions simulating passage through the gastrointestinal tract.

\section{ACKNOWLEDGMENTS}

The authors gratefully thank the Coordenação de Aperfeiçoamento de Pessoal de Nível Superior (CAPES, Brasília, DF, Brazil) for the financial support.

\section{REFERENCES}

Abe, F., H. Miyauchi, A. Uchijima, T. Yaeshima, and K. Iwatsuki. 2009. Stability of bifidobacteria in powdered formula. Int. J. Food Sci. Technol. 44:718-724.

Alves, R. M. V., S. B. M. Jaime, D. Ito, and C. Q. Moreira. 2008. Influence of the barrier properties of flexible packaging on whole milk powder stability. Braz. J. Food Technol. 11:46-53.

Ananta, E., M. Volkert, and D. Knorr. 2005. Cellular injuries and storage stability of spray-dried Lactobacillus rhamnosus GG. Int. Dairy J. 15:399-409.

AOAC International. 2006. Official Methods of Analysis. 18th ed. AOAC International, Gaithersburg, MD

Brody, E. P. 2000. Biological activities of bovine glycomacropeptide. Br. J. Nutr. 84:S39-46.

Brück, W. M., M. Redgrave, K. M. Tuohy, B. Lönnerdal, G. Graverholt, O. Hernell, and G. R. Gibson. 2006. Effects of bovine alphalactalbumin and casein glycomacropeptide-enriched infant formulae on faecal microbiota in healthy term infants. J. Pediatr. Gastroenterol. Nutr. 43:673-679.

Buriti, F. C. A., I. A. Castro, and S. M. I. Saad. 2010. Viability of Lactobacillus acidophilus in synbiotic guava mousses and its survival under in vitro simulated gastrointestinal conditions. Int. J. Food Microbiol. 137:121-129.
Chávez, B. E., and A. M. Ledeboer. 2007. Drying of probiotics: Optimization of formulation and process to enhance storage survival. Drying Technol. 25:1193-1201.

Corcoran, B. M., R. P. Ross, G. F. Fitzgerald, and C. Stanton. 2004. Comparative survival of probiotic lactobacilli spray-dried in the presence of prebiotic substances. J. Appl. Microbiol. 96:10241039.

Crowe, J. H., A. E. Oliver, and F. Tablin. 2002. Is there a single biochemical adaptation to anhydrobiosis? Integr. Comp. Biol. 42:497-503.

De Castro-Cislaghi, F. P., C. Dos, R. E. Silva, C. B. Fritzen-Freire, J. Goulart, and E. S. Sant'Anna. 2012. Bifidobacterium Bb-12 microencapsulated by spray drying with whey: Survival under simulated gastrointestinal conditions, tolerance to $\mathrm{NaCl}$, and viability during storage. J. Food Eng. 113:186-193.

Del Piano, M., M. Ballarè, A. Anderloni, E. Garello, M. Orsello, M. Pagliarulo, L. Morelli, and L. Capurs. 2006a. In vitro sensitivity of probiotics to human bile. Dig. Liver Dis. 38:S130. (Abstr.)

Del Piano, M., M. Ballarè, A. Anderloni, E. Garello, M. Orsello, M. Pagliarulo, L. Morelli, and L. Capurs. 2006b. In vitro sensitivity of probiotics to human gastric juice. Dig. Liver Dis. 38:S134. (Abstr.)

Del Piano, M., P. Strozzi, M. Barba, F. Deidda, P. Lorenzini, S. Allesina, L. Morelli, S. Carmagnola, M. Pagliarulo, M. Balzarini, M. Ballarè, M. Orsello, F. Montino, M. Sartori, E. Garello, and L. Capurso. 2008. In vitro sensitivity of probiotics to human pancreatic juice. J. Clin. Gastroenterol. 42:S170-S173.

Fávaro-Trindade, C. S., and C. R. F. Grosso. 2002. Microencapsulation of L. acidophilus (La-05) and B. lactis (Bb-12) and evaluation of their survival at the $\mathrm{pH}$ values of the stomach and in bile. J. Microencapsul. 19:485-494.

Fox, P. F., and P. L. H. McSweeney. 1998. Dairy Chemistry and Biochemistry. Blackie Academic and Professional, London, UK.

$\mathrm{Fu}, \mathrm{N}$., and X. D. Chen. 2011. Towards a maximal cell survival in convective thermal drying processes. Food Res. Int. 44:1127-1149.

García, A. H. 2011. Anhydrobiosis in bacteria: From physiology to applications. J. Biosci. 36:939-950.

Gardiner, G. E., E. O'Sullivan, J. Kelly, M. A. Auty, G. F. Fitzgerald, J. K. Collins, and C. Stanton. 2000. Comparative survival rates of human-derived probiotic Lactobacillus paracasei and L. salivarius strains during heat treatment and spray drying. Appl. Environ. Microbiol. 66:2605-2612. 
Gaurner, F., A. Khan, J. Garisch, R. Eliakim, A. Gangl, A. Thomson, J. Krabshuis, and T. Mair. 2008. Probiotics and prebiotics. World Gastroenterology Organisation Practice Guidelines. Accessed May 10, 2013. http://www.worldgastroenterology.org/probiotics-prebiotics.html.

Gbassi, G. K., T. Vandamme, S. Ennahar, and E. Marchioni. 2009 Microencapsulation of Lactobacillus plantarum spp in an alginate matrix coated with whey proteins. Int. J. Food Microbiol. 129:103-105.

Gbassi, G. K., T. Vandamme, F. S. Yolou, and E. Marchioni. 2011. In vitro effects of $\mathrm{pH}$, bile salts and enzymes on the release and viability of encapsulated Lactobacillus plantarum strains in a gastrointestinal tract model. Int. Dairy J. 21:97-102.

Gerez, C. L., G. Font de Valdez, M. L. Gigante, and C. R. F. Grosso. 2012. Whey protein coating bead improves the survival of the probiotic Lactobacillus rhamnosus CRL 1505 to low pH. Lett. Appl. Microbiol. 54:552-556.

Goderska, K., and Z. Czarnecki. 2008. Influence of microencapsulation and spray drying on the viability of Lactobacillus and Bifidobacterium strains. Pol. J. Microbiol. 57:135-140.

Golowczyc, M. A., J. Silva, A. G. Abraham, G. L. De Antoni, and P. Teixeira. 2010. Preservation of probiotic strains isolated from kefir by spray drying. Lett. Appl. Microbiol. 50:7-12.

Guerra, A., L. Etienne-Mesmin, V. Livrelli, S. Denis, S. BlanquetDiot, and M. Alric. 2012. Relevance and challenges in modeling human gastric and small intestinal digestion. Trends Biotechnol. 30:591-600.

Hamilton-Miller, J. M., S. Shah, and J. T. Winkler. 1999. Public health issues arising from microbiological and labelling quality of foods and supplements containing probiotic microorganisms. Public Health Nutr. 2:223-229.

IDF. 1993. Dried milk and dried cream-Determination of water content. International Dairy Federation Standard 26A. International Dairy Federation, Brussels, Belgium.

Kitabatake, N., and Y.-I. Kinekawa. 1998. Digestibility of bovine milk whey protein and $\beta$-lactoglobulin in vitro and in vivo. J. Agric. Food Chem. 46:4917-4923.

Lian, W.-C., H.-C. Hsiao, and C.-C. Chou. 2002. Survival of bifidobacteria after spray-drying. Int. J. Food Microbiol. 74:79-86.

Lian, W.-C., H.-C. Hsiao, and C.-C. Chou. 2003. Viability of microencapsulated bifidobacteria in simulated gastric juice and bile solution. Int. J. Food Microbiol. 86:293-301.

Manojlović, V., V. A. Nedovic, and K. Kailasapathy. 2010. Encapsulation of probiotics for use in food products. Pages 269-302 in Encapsulation Technologies for Active Food Ingredients and Food Processing. N. J. Zuidam and V. Nedovic, ed. Springer, New York, NY.

Morgan, C. A., N. Herman, P. A. White, and G. Vesey. 2006. Preservation of micro-organisms by drying: A review. J. Microbiol. Methods 66:183-193.

Mortazavian, A., S. H. Razavi, M. R. Ehsani, and S. Sohrabvandi. 2007. Principles and methods of microencapsulation of probiotic microorganisms. Iran. J. Biotechnol. 5:1-18.

Nijdam, J. J., and T. A. G. Langrish. 2005. An investigation of milk powders produced by a laboratory-scale spray dryer. Drying Technol. 23:1043-1056.

O'Riordan, K., D. Andrews, K. Buckle, and P. Conway. 2001. Evaluation of microencapsulation of a Bifidobacterium strain with starch as an approach to prolonging viability during storage. J. Appl. Microbiol. 91:1059-1066.

O'Toole, P. W., and J. C. Cooney. 2008. Probiotic bacteria influence the composition and function of the intestinal microbiota. Interdiscip. Perspect. Infect. Dis. 2008:175285. http://dx.doi. org/10.1155/2008/175285.

Oliveira, A. C., T. S. Moretti, C. Boschini, J. C. C. Baliero, O. Freitas, and C. S. Fávaro-Trindade. 2007. Stability of microencapsulated B. lactis (BI 01) and L. acidophilus (LAC 4) by complex coacervation followed by spray drying. J. Microencapsul. 24:673-681.
Paéz, R., L. Lavari, G. Vinderola, G. Audero, A. Cuatrin, N. Zaritzky, and J. Reinheimer. 2012. Effect of heat treatment and spray drying on lactobacilli viability and resistance to simulated gastrointestinal digestion. Food Res. Int. 48:748-754.

Peighambardoust, S. H., A. Golshan Tafti, and J. Hesari. 2011. Application of spray drying for preservation of lactic acid starter cultures: A review. Trends Food Sci. Technol. 22:215-224.

Picot, A., and C. Lacroix. 2004. Encapsulation of bifidobacteria in whey protein-based microcapsules and survival in simulated gastrointestinal conditions and in yoghurt. Int. Dairy J. 14:505-515.

Prakash, S., C. Tomaro-Duchesneau, S. Saha, and A. Cantor. 2011. The gut microbiota and human health with an emphasis on the use of microencapsulated bacterial cells. J. Biomed. Biotechnol. 2011:981214. http://dx.doi.org/10.1155/2011/981214.

R Development Core Team. 2011. R: A language and environment for statistical computing. R Foundation for Statistical Computing, Vienna, Austria. http://www.R-project.org.

Ranadheera, R. D. C. S., S. K. Baines, and M. C. Adams. 2010. Importance of food in probiotic efficacy. Food Res. Int. 43:1-7.

Reddy, K. B. P. K., A. N. Madhu, and S. G. Prapulla. 2009. Comparative survival and evaluation of functional probiotic properties of spray-dried lactic acid bacteria. Int. J. Dairy Technol. 62:240-248.

Reid, G., M. E. Sanders, H. R. Gaskins, G. R. Gibson, A. Mercenier, R. Rastall, M. Roberfroid, I. Rowland, C. Cherbut, and T. R. Klaenhammer. 2003. New scientific paradigms for probiotics. J. Clin. Gastroenterol. 37:105-118.

Rodríguez-Huezo, M. E., R. Durán-Lugo, L. A. Prado-Barragán, F. Cruz-Sosa, C. Lobato-Calleros, J. Alvarez-Ramírez, and E. J. Vernon-Carter. 2007. Pre-selection of protective colloids for enhanced viability of Bifidobacterium bifidum following spray-drying and storage, and evaluation of aguamiel as thermoprotective prebiotic. Food Res. Int. 40:1299-1306.

Santivarangkna, C., B. Higl, and P. Foerst. 2008a. Protection mechanisms of sugars during different stages of preparation process of dried lactic acid starter cultures. Food Microbiol. 25:429-441.

Santivarangkna, C., U. Kulozik, and P. Foerst. 2008b. Inactivation mechanisms of lactic acid starter cultures preserved by drying processes. J. Appl. Microbiol. 105:1-13.

Schuck, P. 2011. Dehydrated dairy products. Milk powder: Types and manufacture. Pages 108-116 in Encyclopedia of Dairy Sciences. J. W. Fuquay, ed. 2nd ed. Academic Press, San Diego, CA.

Silva, J., R. Freixo, P. Gibbs, and P. Teixeira. 2011. Spray-drying for the production of dried cultures. Int. J. Dairy Technol. 64:321335.

Simpson, P. J., C. Stanton, G. F. Fitzgerald, and R. P. Ross. 2005 Intrinsic tolerance of Bifidobacterium species to heat and oxygen and survival following spray drying and storage. J. Appl. Microbiol. 99:493-501.

Souza, F. N., C. Gebara, M. C. E. Ribeiro, K. S. Chaves, M. L. Gigante, and C. R. F. Grosso. 2012. Production and characterization of microparticles containing pectin and whey proteins. Food Res. Int. 49:560-566.

Tappenden, K. A. 2012. Probiotics are not a one-species-fits-all proposition. JPEN J. Parenter. Enteral Nutr. 36:496.

Teixeira, P., H. Castro, and R. Kirby. 1996. Evidence of membrane lipid oxidation of spray-dried Lactobacillus bulgaricus during storage. Lett. Appl. Microbiol. 22:34-38.

Ying, D. Y., M. C. Phoon, L. Sanguansri, R. Weerakkody, I. Burgar, and M. A. Augustin. 2010. Microencapsulated Lactobacillus rhamnosus GG powders: Relationship of powder physical properties to probiotic survival during storage. J. Food Sci. 75:E588-E595.

Zhao, R., J. Sun, P. Torley, D. Wang, and S. Niu. 2008. Measurement of particle diameter of Lactobacillus acidophilus microcapsule by spray drying and analysis on its microstructure. World J. Microbiol. Biotechnol. 24:1349-1354. 